\title{
A new synthesis of Entacapone and report on related studies
}

\author{
ATTIMOGAE SHIVAMURTHY HARISHA ${ }^{\mathrm{a}, \mathrm{b}}$, SURESH PARAMESHWAR NAYAK ${ }^{\mathrm{b}}$, \\ PAVAN M $\mathrm{S}^{\mathrm{c}}$, SHRIDHARA K ${ }^{\mathrm{a}}$, SUNDARRAJA RAO K ${ }^{\mathrm{a}}$, RAJENDRA K ${ }^{\mathrm{d}}$, KOTEPPA PARI ${ }^{\mathrm{d}}$, \\ SIVARAMKRISHNAN $\mathrm{H}^{\mathrm{d}}$, GURU ROW $\mathrm{T} \mathrm{N}^{\mathrm{c}, *}$ and KUPPUSWAMY NAGARAJAN ${ }^{\mathrm{a}, *}$ \\ ${ }^{a}$ Alkem Laboratories Ltd., R \& D Centre, Industrial Estate, $4^{\text {th }}$ Phase, Bangalore 560058 , India \\ ${ }^{b}$ Department of Chemistry, Mangalore University, Mangalagangothri, Mangalore 574 199, India \\ ${ }^{\mathrm{c}}$ Solid State and Structural Chemistry Unit, Indian Institute of Science, Bangalore 560 012, India \\ ${ }^{d}$ Piramal Life Sciences, Piramal Health Care, Mumbai, Maharashtra 400 030, India \\ e-mail: ssctng@sscu.iisc.ernet.in; dknb69@yahoo.com
}

MS received 30 April 2015; revised 1 June 2015; accepted 28 August 2015

\begin{abstract}
A new synthesis of the catechol- $O$-methyltransferase (COMT) inhibitor, entacapone (E-isomer) has been achieved under mild conditions by amine-mediated demethylation of the precursor 2-Cyano-3-(3hydroxy-4-methoxy-5-nitrophenyl) prop-2-eneamide, wherein the methoxyl group adjacent to a nitro group gets demethylated under nucleophilic attack. Similar demethylation was achieved on ethyl 2-cyano-3-(3, 4-dimethoxy-5-nitrophenyl) prop-2-enoate, 2-cyano-3-(3,4-dimethoxy-5-nitrophenyl)-N,N-diethylprop-2-enamide, ethyl 2-cyano-3-(3-hydroxy-4-methoxy-5-nitrophenyl) prop-2-enoate and ethyl 2-cyano-3-(4-methoxy3 -nitrophenyl) prop-2-enoate. The scope of demethylation has been studied. Analogues of ethyl 2-cyano-3-(3, 4-dimethoxy-5-nitrophenyl) prop-2-enoate wherein a methoxyl group is not adjacent to a $\mathrm{NO}_{2}$ group are unaffected and phenolic derivatives yield the amine salts. Entacapone has been converted to salts with organic bases. The crystal structure of the isomer of entacapone (Z-isomer), a significant human metabolite of E-isomer has been established. NMR methods for deriving $\mathrm{E}$ and $\mathrm{Z}$ geometry and other similar molecules have been successfully established, mainly by studying the proton coupled ${ }^{13} \mathrm{C}$ spectra. Preliminary studies reveal in vitro activity for some compounds against tuberculosis (TB) and dengue.
\end{abstract}

Keywords. Mild demethylation; crystal structure; entacapone; Z-isomer; carbon, proton NMR;

E, Z geometry.

\section{Introduction}

Parkinson's disease (PD) ${ }^{1}$ described by James Parkinson in 1817 , is one of the most common, intriguing and debilitating neurological diseases affecting almost five million people today. PD is a progressive degenerative disease that usually causes severe disability after 10 to 15 years, causing a heavy social and financial burden, especially on the elderly, estimated to cost about 10 to 11 billion USD in terms of drug treatment. ${ }^{2,3}$ Among the currently available symptomatic interventions for the pharmacological treatment of PD, therapy with LDOPA in combination with a DOPA decarboxylase is widely prescribed. During such treatment, the enzyme COMT $^{4,5}$ metabolizes L-DOPA by another mechanism and reduces its availability. ${ }^{6,7}$ COMT inhibitors have been developed to inhibit this enzyme and increase

*For correspondence the bioavailability of L-DOPA. ${ }^{8}$ Among them, the nitro catechol derivative entacapone $\mathbf{1}$ has found high acceptance as an adjunct for treatment by L-DOPA. Entacapone, having the E geometry shown in formula $\mathbf{1}$, has been the object of some synthetic, X-ray crystallographic and NMR studies. The crystal structure of $\mathbf{2}$ ( $\mathrm{Z}$ isomer), which has been identified as one of the major metabolites in humans ${ }^{9}$ has not been reported so far. We have achieved a new approach to the synthesis of $\mathbf{1}$ and some analogues under mild conditions and studied its scope. The results have been reported in a preliminary communication. ${ }^{23}$ We present full experimental details of the demethylation reaction and extension to some similar substrates where demethylation does not occur Amine salts are formed or starting materials are recovered. ${ }^{23} \mathrm{~A}$ few amine salts of water insoluble $\mathbf{1}$ have been prepared. ${ }^{23}$ Also recorded are derivation of the single crystal X-ray structure of $\mathbf{2}$ and extensive application of NMR techniques for deriving the geometry of such molecules. 


\section{Experimental}

\subsection{General information}

All reagents were purchased from commercial sources and used without further treatment, unless otherwise indicated. The products were purified by column chromatography over silica gel 230-400 mesh. ${ }^{1} \mathrm{H}$ NMR spectra were recorded on 300,400 or $500 \mathrm{MHz}$ and ${ }^{13} \mathrm{C}$ spectra on 75 or $125 \mathrm{MHz}$. $\mathrm{CDCl}_{3}$ was the solvent used generally and DMSO-d6 occasionally with TMS as an internal standard. Melting points were determined with a Buchi-545 instrument. HPLC chromatograms were recorded with an Agilent 1200 instrument.

2.1a Ethyl 2-cyano-3-(3, 4-dimethoxy-5-nitrophenyl) prop-2-enoate (4): Ethyl cyanoacetate (11.3 g, 0.1 mol) was taken in ethanol (100 mL) to which 2-3 drops piperidine were added and the mixture stirred for 10-15 min. 3,4-Dimethoxy-5-nitrobenzaldehyde (21.1 g, 0.1 mol) was added slowly to the mixture which was then heated to reflux until a TLC test showed the reaction was complete. The mixture was cooled to $25-30^{\circ} \mathrm{C}$, the precipitate was filtered off, washed with ethanol and then recrystallized from the same solvent to afford 4 . $81 \%$ was the isolated yield as off white solid. MR:118$119^{\circ} \mathrm{C} ;{ }^{1} \mathrm{H}-\mathrm{NMR}\left(400 \mathrm{MHz}, \mathrm{CDCl}_{3}\right): \delta 1.40(\mathrm{t}, J=$ $7.1 \mathrm{~Hz}, 3 \mathrm{H}), 4.00(\mathrm{~s}, 3 \mathrm{H}), 4.08(\mathrm{~s}, 3 \mathrm{H}), 4.40(\mathrm{q}, J=$ $7.1 \mathrm{~Hz}, 2 \mathrm{H}), 7.70(\mathrm{~d}, J=1.7 \mathrm{~Hz}, \operatorname{Ar}-\mathrm{H}), 8.04(\mathrm{~d}, J=$ 1.7Hz, Ar-H), 8.14 (s, 1H), ms: m/z 305.9(negative mode).

2.1b Ethyl 2-cyano-5-(4-hydroxy-3-methoxy-5-nitrophenyl) prop-2-enoate (6)- demethylation of (4): A solution of $4(3.0 \mathrm{~g}, 0.01 \mathrm{~mol})$ and triethylamine $(3.03 \mathrm{~g}, 0.03$ $\mathrm{mol}$ ) in ethanol was heated to $70-75^{\circ} \mathrm{C}$ for $12 \mathrm{~h}$. Ethanol was distilled off, the residue was dissolved in water, the solution acidified with dilute hydrochloric acid and the product extracted into ethyl acetate. The organic layer was dried with sodium sulphate and evaporated to get the crude demethylated product. This was purified using silica gel column chromatography (hexane/ethylacetate as mobile phase) to afford $\mathbf{6 , 6 0 \%}$ isolated yield as light yellow solid. MR: $165-166^{\circ} \mathrm{C}$; $1 \mathrm{H}-\mathrm{NMR}(400 \mathrm{MHz}$, DMSO): $\delta 1.28$ (t, $J=7.0 \mathrm{~Hz}, 3 \mathrm{H}), 3.90(\mathrm{~s}, 3 \mathrm{H}), 4.30(\mathrm{q}$, $J=7.0 \mathrm{~Hz}, 2 \mathrm{H}$ ), 7.96(unresolved doublet, Ar-H), 8.30 (unresolved doublet, Ar-H), 8.35(1H, s), 11.01(br s, -OH), ms: $m / z$ 291.8.

In another experiment, the crude reaction mass was dissolved in water, the solution acidified with hydroiodic acid and the product $\mathbf{6}$ extracted into ethylacetate.
The aqueous layer was evaporated to isolate methyltriethylammonium iodide salt 7 , MR: $327-328^{\circ} \mathrm{C} ; 1 \mathrm{H}$ NMR $\left(400 \mathrm{MHz}, \mathrm{D}_{2} \mathrm{O}\right): \delta 1.30(\mathrm{~m}, 9 \mathrm{H}), 2.93(\mathrm{~s}, 3 \mathrm{H})$, $3.32(\mathrm{q}, J=7.0 \mathrm{~Hz}, 6 \mathrm{H})$, identical with a sample prepared as per literature procedure, ${ }^{22} \mathrm{MR}: 329-330^{\circ} \mathrm{C}$ (mixed MR: $327-328^{\circ} \mathrm{C}$ ).

Compound 6 obtained above was identical with an authentic sample got by heating ethyl cyanoacetate and 3-methoxy-4-hydroxy-5-nitrobenzaldehyde in ethanol using the conditions employed for 4. MR: $165-166^{\circ} \mathrm{C}$ (mixed MR: $164-165^{\circ} \mathrm{C}$ ).

2.1c 2-Cyano-N,N-diethyl-3-(4-hydroxy-3-methoxy-5nitrophenyl) prop-2-enamide (10): Compound 9 (3.3 $\mathrm{g}, 0.01 \mathrm{~mol})$ was subjected to reaction with triethylamine in ethanol as under 6. Ethanol was distilled off and the residue was dissolved in water, acidified under cooling with dilute hydroiodic acid; the product was extracted into ethyl acetate, dried organic layer was evaporated to get the crude demethylated product. This was purified by silica gel column chromatography using (hexane/ethyl acetate as mobile phase) to afford 10. 56\% isolated yield as yellow solid. MR: $109-110^{\circ} \mathrm{C} ;{ }^{1} \mathrm{H}$ NMR (400 MHz, $\mathrm{CDCl}_{3}$ ): $\delta 1.27$ (br s, $6 \mathrm{H}), 3.50$ (br s, 4H), 4.02 (s, 3H), 7.60 (s, 1H), 7.98 (d, $J=1.9 \mathrm{~Hz}, \mathrm{Ar}-\mathrm{H}), 8.02(\mathrm{~d}, J=1.9 \mathrm{~Hz}, \mathrm{Ar}-\mathrm{H}), 11.06$ (br s, -OH); ms: $m / z 318.1$ (negative mode). This was identical with an authentic sample $,{ }^{11} \mathrm{MR}: 106-108^{\circ} \mathrm{C}$ (mix MR: $105-108^{\circ} \mathrm{C}$ ).

2.1d Ethyl 2-cyano-3-(3-hydroxy-4-methoxy-5-nitrophenyl) prop-2-enoate (11): This was prepared from isonitrovanillin and ethyl cyanoacetate according to the conditions used for 4 . It was recrystallized from ethanol to afford pure 11. $86 \%$ isolated yield as off white solid. MR: $189-190{ }^{\circ} \mathrm{C} ;{ }^{1} \mathrm{H}-\mathrm{NMR}$ (400 MHz, DMSO): $\delta 1.29$ $(\mathrm{t}, J=7.1 \mathrm{~Hz}, 3 \mathrm{H}), 3.95(3 \mathrm{H}, \mathrm{s}), 4.29(\mathrm{q}, J=7.0 \mathrm{~Hz}$, $2 \mathrm{H}), 7.91(\mathrm{~d}, J=2.1 \mathrm{~Hz}, \operatorname{Ar}-\mathrm{H}), 7.95(\mathrm{~d}, J=2.1 \mathrm{~Hz}$, Ar-H), 8.33 (s, 1H), 11.12(br s,-OH); ms: m/z 291.1 (negative mode); Analysis: Calcd (\%) for $\mathrm{C}_{13} \mathrm{H}_{12} \mathrm{~N}_{2} \mathrm{O}_{6}$ (292.24): C 53.42, H 4.14, N 9.58. Found (\%): C 53.43, H 3.65, N 9.52.

2.1e Ethyl 2-cyano-3-(3,4-dihydroxy-5-nitrophenyl)prop2-enoate (12): Demethylation of $\mathbf{1 1}(2.92 \mathrm{~g}, 0.01 \mathrm{~mol})$ with triethylamine in ethanol was carried out as per 6. The crude product was recrystallized with ethyl acetate to afford 12. $48 \%$ isolated yield as light yellow powder. MR: $205-206^{\circ} \mathrm{C}$ ( lit. $^{22}: 205-206^{\circ} \mathrm{C}$ ); ${ }^{1} \mathrm{H}-\mathrm{NMR}$ (400 MHz, DMSO): $\delta 1.28(\mathrm{t}, J=7.0 \mathrm{~Hz}, 3 \mathrm{H}), 4.29$ (q, $J=7.1 \mathrm{~Hz}, 2 \mathrm{H}), 7.82(\mathrm{~d}, J=2.0 \mathrm{~Hz}, \mathrm{Ar}-\mathrm{H}), 8.07$ (d, 
$J=2.0 \mathrm{~Hz}$, Ar-H), $8.22(\mathrm{~s}, 1 \mathrm{H}), 10.71$ (br s,2-OH); ms: $\mathrm{m} / \mathrm{z}$ 277.0(negative mode); HRMS(EI): $\mathrm{m} / \mathrm{z}(\%)$ : calcd for $\mathrm{C}_{12} \mathrm{H}_{10} \mathrm{~N}_{2} \mathrm{O}_{6} \mathrm{Na}$ : 301.0437; found: 301.0455 .

2.1f 2-Cyano-3-(3-hydroxy-4-methoxy-5-nitrophenyl) prop-2-eneamide (13): To a solution of $N, N$ diethylcyanoacetamide $(14.1 \mathrm{~g}, 0.1 \mathrm{~mol})$ in toluene was added 0.2 g IRA 96 resin and isonitrovanillin (19.7 $\mathrm{g}, 0.1 \mathrm{~mol})$. The mixture was heated to reflux with azeotropic distillation of water. The reaction was continued until a TLC test showed completion of reaction. The mass was filtered hot. The filtrate was concentrated under vacuum to give the crude product, which was recrystallized from absolute alcohol to afford 13. $61 \%$ isolated yield as light yellow solid. MR: $175-176^{\circ} \mathrm{C}$; ${ }^{1} \mathrm{H}-\mathrm{NMR}$ (400 MHz, DMSO): $\delta 1.13$ (br s, 6H), 3.39 (br s, 4H), 3.92 (s, 3H), $7.67(\mathrm{~s}, 1 \mathrm{H}), 7.76(\mathrm{~d}, \mathrm{~J}=2.1 \mathrm{~Hz}$, Ar-H), 7.78 (d, J =2.1Hz, Ar-H), 10.98 (br s,-OH); ms: $\mathrm{m} / \mathrm{z} 318.1$ (negative mode).

2.1g (2E)-2-Cyano-3-(3, 4-dihydroxy-5-nitrophenyl)$N, N$-diethylprop-2-enamide, entacapone (1): Acrylamide 13 (3.19, $0.01 \mathrm{~mol})$ was demethylated with triethylamine in ethanol at $70-75^{\circ} \mathrm{C}$ for $12 \mathrm{~h}$. After completion of the reaction, the intermediate salt $(2.9 \mathrm{~g})$ was isolated by distilling off the solvent. The salt was dissolved in water, acidified with hydrochloric acid, and the product extracted into ethyl acetate. The dried organic layer was evaporated to get the crude demethylated product. This was purified through silica gel column chromatography using hexane/ethyl acetate as mobile phase to afford pure 1. $45 \%$ isolated yield as yellow solid. MR: $162-163^{\circ} \mathrm{C}$ (lit. ${ }^{10}: 162-163^{\circ} \mathrm{C}$ ). ${ }^{1} \mathrm{H}-$ NMR (400 MHz, $\mathrm{CDCl}_{3}$ ): $\delta 1.20$ (br s, 6H), 3.43 (br s,4H), $7.44(\mathrm{~s}, 1 \mathrm{H}), 7.84$ (unresolved doublet, Ar-H), 7.94 (unresolved doublet, $1 \mathrm{ArH}$ ), 9.67(br s, $-\mathrm{OH}), 10.79$ (br s, $-\mathrm{OH}) ;{ }^{13} \mathrm{C}-\mathrm{NMR}\left(\mathrm{CDCl}_{3}, 75 \mathrm{MHz}\right): \delta 162.90$, 148.96, 148.36, 146.88, 133.81,124.03 120.69, 118.41, $116.62,107.08,43.42,40.72,13.50,12.50 ; \mathrm{ms}: \mathrm{m} / \mathrm{z}$ $=304.1$ (negative mode); HPLC purity $>99 \%$. The yield of 1 was increased to $55 \%$ when the reaction time was extended to $14 \mathrm{~h}$.

2.1h Diethylamine salt of ethyl 2-cyano-3-(4-hydroxy3-methoxy-5-nitrophenyl) prop-2-enoate (15): Attempted demethylation of $\mathbf{6}$ with diethylamine in ethanol gave only the salt 15. 88\% isolated yield as yellow solid. MR: $128-129^{\circ} \mathrm{C} ;{ }^{1} \mathrm{H}-\mathrm{NMR}\left(400 \mathrm{MHz}, \mathrm{CDCl}_{3}\right): \delta 1.25(\mathrm{t}, J=$ $7.2 \mathrm{~Hz}, 6 \mathrm{H}), 1.32(\mathrm{t}, \mathrm{J}=7.2 \mathrm{~Hz}, 3 \mathrm{H}), 2.94(\mathrm{q}, \mathrm{J}=7.1 \mathrm{~Hz}$,
4H), $3.64(\mathrm{~s}, 3 \mathrm{H}), 4.23$ (q, J $J=7.1 \mathrm{~Hz}, 2 \mathrm{H}), 7.47(\mathrm{~s}, 1 \mathrm{Ar}-$ H), 7.89 (s, -H), 7.90(s, 1Ar-H), 8.10 (s,1Ar-H),8.25 (br s, -OH).

2.1i Ethyl 2-cyano-3-(4-methoxy-3-nitrophenyl) prop2-enoate (16): This was prepared from reaction of ethyl cyanoacetate and 4-methoxy-3-nitrobenzaldehyde $(18.1 \mathrm{~g}, 0.1 \mathrm{~mol})$ in ethanol as usual. The product was recrystallized with ethanol to afford $\mathbf{1 6 . 6 5 \%}$ isolated yield as off white solid. MR: $187-188^{\circ} \mathrm{C} .{ }^{1} \mathrm{H}$ NMR (400 $\left.\mathrm{MHz} ; \mathrm{CDCl}_{3}\right) \delta 1.39(\mathrm{t}, J=7.2 \mathrm{~Hz}, 3 \mathrm{H}), 4.06(\mathrm{~s}, 3 \mathrm{H})$, 4.39 (q, $J=7.2 \mathrm{~Hz}, 2 \mathrm{H}), 7.23(\mathrm{~d}, J=5.4 \mathrm{~Hz}, \mathrm{Ar}-\mathrm{H})$, $8.16(\mathrm{~s}, 1 \mathrm{H}), 8.36(\mathrm{~d}, J=2.8 \mathrm{~Hz}, \operatorname{Ar}-\mathrm{H}), 8.38(\mathrm{~d}, J=$ 5.4, 2.8Hz, Ar-H); ms: m/z 277.2 (positive mode).

2.1j Ethyl 2-cyano-3-(4-hydroxy-3-nitrophenyl) prop2-enoate (17): Demethylation was carried out on 16 $(2.7 \mathrm{~g}, 0.01 \mathrm{~mol})$ under standard conditions. The crude product was crystallized from ethanol to afford crude 17. $57 \%$ isolated yield as red solid. MR: $169-170^{\circ} \mathrm{C} .{ }^{1} \mathrm{H}-$ NMR (400 MHz, $\left.\mathrm{CDCl}_{3}\right) \delta: 1.39$ (t, $\left.J=7.2 \mathrm{~Hz}, 3 \mathrm{H}\right)$, $4.04(\mathrm{q}, J=7.2 \mathrm{~Hz}, 2 \mathrm{H}), 7.31(\mathrm{~d}, J=8.7 \mathrm{~Hz}, A r-\mathrm{H})$, $8.18(\mathrm{~s}, 1 \mathrm{H}), 8.40(\mathrm{dd}, J=8.8,2.2 \mathrm{~Hz}, \mathrm{Ar}-\mathrm{H}), 8.60$ (d, $J=2.1 \mathrm{~Hz}, \mathrm{Ar}-\mathrm{H}$ ), 10.9 (br s, $-\mathrm{OH}$ ); ms: m/z 261.0 (negative mode).

2.1k Ethyl 2-cyano-3-(3-methoxy-2-nitrophenyl) prop2-enoate (19): This was prepared from 3-methoxy-2nitrobenzaldehyde $(18.1 \mathrm{~g})$ under standard conditions. $85 \%$ isolated yield as colorless solid. MR: $139-140^{\circ} \mathrm{C}$; ${ }^{1} \mathrm{H}-\mathrm{NMR}\left(400 \mathrm{MHz}, \mathrm{CDCl}_{3}\right): \delta 1.41(\mathrm{t}, J=7.2 \mathrm{~Hz}$, $3 \mathrm{H}), 3.98(\mathrm{~s}, 3 \mathrm{H}), 4.39(\mathrm{q}, J=7.2 \mathrm{~Hz}, 2 \mathrm{H}), 7.27(\mathrm{~d}$, $J=8.4 \mathrm{~Hz}, \operatorname{Ar}-\mathrm{H}), 7.61(\mathrm{t}, J=8.1 \mathrm{~Hz}, \operatorname{Ar}-\mathrm{H}), 7.80(\mathrm{~d}$, $J=8.1 \mathrm{~Hz}, \operatorname{Ar}-\mathrm{H}), 8.15$ (s, 1H); ms: m/z 295.6 water adduct (positive mode).

2.11 Diethylamine salt of 2-cyano- $N, \mathrm{~N}$-diethyl-3-(4hydroxy-3-methoxyphenyl)prop-2-enamide $22 \quad(\boldsymbol{R}=\mathbf{N}$ $\left.\boldsymbol{E} t_{2}\right)$ : Attempted demethylation of $\mathbf{2 0}\left(\mathrm{R}=\mathrm{N} \quad \mathrm{Et}_{2}\right)$ $(2.74 \mathrm{~g} 0.01 \mathrm{~mol})$ made from vanillin and $N, N$ diethylcyanoacetamide under standard conditions with diethylamine gave only the salt. $76 \%$ isolated yield as yellow solid. MR: $140-141{ }^{\circ} \mathrm{C} ;{ }^{1} \mathrm{H}$ NMR (400 MHz, $\left.\mathrm{CDCl}_{3}\right): \delta 1.2(\mathrm{t}, 6 \mathrm{H}), 1.27$ ( br t, 6H), 2.82(q, $J=7.1 \mathrm{~Hz}, 4 \mathrm{H}), 3.52(\mathrm{q}, J=7.1 \mathrm{~Hz}, 4 \mathrm{H}), 3.90(\mathrm{~s}, 3 \mathrm{H})$, 6.81 (unresolved dd, $1 \mathrm{ArH}), 7.26(\mathrm{~d}, J=6.9 \mathrm{~Hz}, 1 \mathrm{ArH})$, $7.62(\mathrm{~s}, \mathrm{H}), 7.72(\mathrm{~d}, J=2.1 \mathrm{~Hz}, 1 \mathrm{ArH})$.

$2.1 \mathrm{~m}$ Diethylamine salt (23) of (21): Attempted demethylation of 21 (2.47 g, $0.01 \mathrm{~mol}$ ) made from vanillin and ethyl cyanoacetate with diethylamine 
$(2.2 \mathrm{~g}, 0.03 \mathrm{~mol})$ in ethanol at $50-55^{\circ} \mathrm{C}$ for $11 \mathrm{~h}$ gave 23 . $85 \%$ isolated yield as light red solid. MR: $134-135^{\circ} \mathrm{C}$; ${ }^{1} \mathrm{H}-\mathrm{NMR}$ (400 MHz, DMSO): $\delta 1.09$ (t, $J=7.2 \mathrm{~Hz}$, $6 \mathrm{H}), 1.26(\mathrm{t}, J=7.0 \mathrm{~Hz}, 3 \mathrm{H}), 2.80(\mathrm{q}, J=7.2 \mathrm{~Hz}, 4 \mathrm{H})$, $3.68(\mathrm{~s}, 3 \mathrm{H}), 4.18(\mathrm{q}, J=7.0 \mathrm{~Hz}, 2 \mathrm{H}), 6.35(\mathrm{~d}$, $J=8.6 \mathrm{~Hz}, 1 \mathrm{ArH}), 7.34(\mathrm{q}, J=6.7,1.8 \mathrm{~Hz}, 1 \mathrm{ArH}), 7.66$ (d, $J=1.8 \mathrm{~Hz}, 1 \mathrm{ArH}), 7.80(\mathrm{~s}, 1 \mathrm{H})$.

2.1n Ethyl 2-cyano-3-(4-hydroxy-3, 5-dimethoxyphenyl) prop-2-enoate (24): Condensation of 4-hydroxy-3, 5dimethoxybenzaldehyde $(18.2 \mathrm{~g}, 0.1 \mathrm{~mol})$ with ethyl cyanoacetate $(11.3 \mathrm{~g}, 0.1 \mathrm{~mol})$ gave $24.80 \%$ isolated yield as yellow solid. MR: $177-178^{\circ} \mathrm{C} ;{ }^{1} \mathrm{H}-\mathrm{NMR}(300$ $\mathrm{MHz}, \mathrm{DMSO}): \delta 1.3$ (t, $J=6.0 \mathrm{~Hz}, 3 \mathrm{H}), 3.82(\mathrm{~s}, 6 \mathrm{H})$, 4.31 (q, $J=6.0 \mathrm{~Hz}, 2 \mathrm{H}), 7.53(\mathrm{~s}, 2 \mathrm{Ar}-\mathrm{H}), 8.26(\mathrm{~s}, 1 \mathrm{H})$, 9.98 (s,-OH); ms: m/z 276.0 (negative mode).

2.1o Diethylamine salt of ethyl 2-cyano-3-(4hydroxy-3, 5-dimethoxyphenyl)prop-2-enoate (25). $\left(B=E t_{2} N\right)$ : Attempted demethylation of $\mathbf{2 4}$ with diethylamine in ethanol gave the salt $\mathbf{2 5}$. 88\% isolated yield as dark yellow solid. MR: $190-191^{\circ} \mathrm{C}$. ${ }^{1} \mathrm{H}-\mathrm{NMR}(300 \mathrm{MHz}, \mathrm{DMSO}): \delta 1.14(\mathrm{t}, J=6.0 \mathrm{~Hz}, 6 \mathrm{H})$, $1.25(\mathrm{t}, J=6.0 \mathrm{~Hz}, 3 \mathrm{H}), 2.85(\mathrm{q}, J=6.0 \mathrm{~Hz}, 4 \mathrm{H}), 3.77$ $(\mathrm{s}, 6 \mathrm{H}), 4.25$ (q, $J=6.0 \mathrm{~Hz}, 2 \mathrm{H}), 7.28(\mathrm{~s}, 2 \mathrm{Ar}-\mathrm{H}), 7.34$ (s, 1H), 7.97 (s,-OH); ms: $m / z 274.9$ (positive mode).

2.1p Piperidine salt of ethyl-2-cyano-3-(4-hydroxy3, 5-dimethoxyphenyl) prop-2-enoate (26): The piperidine salt $\mathbf{2 6}$ of $\mathbf{2 4}$ resulted when demethylation was attempted with piperidine. $80 \%$ isolated yield as yellow solid. MR: $146-147^{\circ} \mathrm{C} .{ }^{1} \mathrm{H}-\mathrm{NMR}(300 \mathrm{MHz}, \mathrm{DMSO}) \delta$ : $1.23(\mathrm{t}, J=7.06 \mathrm{~Hz}, 3 \mathrm{H}), 1.55(6 \mathrm{H}, \mathrm{m}), 2.95(4 \mathrm{H}, \mathrm{m})$, 3.80 (s, 6H), 4.18 (q, $J=7.06 \mathrm{~Hz}, 2 \mathrm{H}), 7.27$ (br s, 2H), 7.73(s, 1H); ms: m/z 277.0 positive mode).

2.1q 2-Cyano-N, N-diethyl-3-(3-hydrox-4-methoxyphenyl) prop-2-enamide (28): Condensation of 3-hydroxy-4methoxybenzaldehyde under conditions used for $\mathbf{1 3}$ gave 28, which was recrystallized with methanol. 74\% isolated yield as light yellow solid. MR: $131-132^{\circ} \mathrm{C}$; ${ }^{1} \mathrm{H}-\mathrm{NMR}$ (400 MHz, CDCl3) $\delta: 1.24$ (br s, 6H), 3.3 (br s, 4H), $3.96(\mathrm{~s}, 3 \mathrm{H}), 6.92(\mathrm{~d}, J=8.4 \mathrm{~Hz}, \mathrm{Ar}-\mathrm{H}), 7.45$ (dd, $J=6.2,2.1 \mathrm{~Hz}, A r-H), 7.5(\mathrm{~d}, J=2.1 \mathrm{~Hz}, A r-\mathrm{H})$, $7.57(\mathrm{~s}, 1 \mathrm{H}) ; \mathrm{ms} \mathrm{m} / \mathrm{z} 275.2$ (positive mode). Reaction of 28 with triethylamine under standard conditions led to its recovery.

2.1r Amine salts of Entacapone: These were prepared by treating a solution of entacapone $(0.01 \mathrm{~mol})$ in ethanol with the appropriate amine $(0.01 \mathrm{~mol})$. The reaction mass was stirred for $25-30 \mathrm{~min}$ at $25-30^{\circ} \mathrm{C}$.
When salt formation was complete, the precipitated salt solid was filtered and dried to afford the product.

2.1s Diethyl amine salt (30): $92 \%$ isolated yield as light yellow solid. MR: $205-206^{\circ} \mathrm{C}$.

2.1t Triethylamine salt (31): $78 \%$ isolated yield as red colored solid. MR: $203-204^{\circ} \mathrm{C}$.

2.1u Piperidine salt (32): $77 \%$ isolated yield as yellow solid. MR: $156-159^{\circ} \mathrm{C}$.

2.1v Di-isopropyl ethylamine salt (33): $80 \%$ isolated yield as yellow solid. MR: $102-103^{\circ} \mathrm{C}$.

2.1w Morpholine salt (34): $76 \%$ isolated yield as red colored solid. MR: $156-157^{\circ} \mathrm{C}$.

\section{Results and Discussion}

\subsection{Demethylation by nucleophilic attack}

Currently available methods for the synthesis of entacapone $\mathbf{1}$ are generally covered by scheme $1 .{ }^{10-15}$

In the above processes, the nitro catechol moiety is formed at an early or late stage by demethylation of a nitrovertraldehyde or nitrovanillin derivative carrying the entacapone side chain using harsh and corrosive reagents such as aluminum chloride, hydrobromic acid, boron trichloride, thiophenol etc. In general methyl aryl ethers can be cleaved under similar harsh conditions using pyridine hydrochloride alone under microwave irradiation ${ }^{16}$ or in a high boiling solvent. Buckle et al., ${ }^{17}$ reported dealkylation of (2methoxyphenyl) ethynes using lithium iodide in refluxing 2, 4, 6-trimethylpyridine. ${ }^{18}$ Nishioka et al.,${ }^{19}$ found that ortho anisic acid can be demethylated with aliphatic amines in high boiling aprotic solvents like DMSO, DMF, and dimethyl acetamide at temperatures around $150^{\circ} \mathrm{C}$. It occurred to us that it may be possible to synthesize 1 under mild basic conditions from nitrocatechol precursors like 3 .

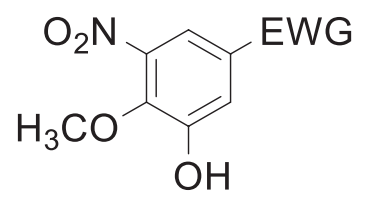

3

wherein the methoxyl group on C-4 having strong electron withdrawing groups $(\mathrm{EWG})$ at the ortho $\left(\mathrm{NO}_{2}\right)$ 


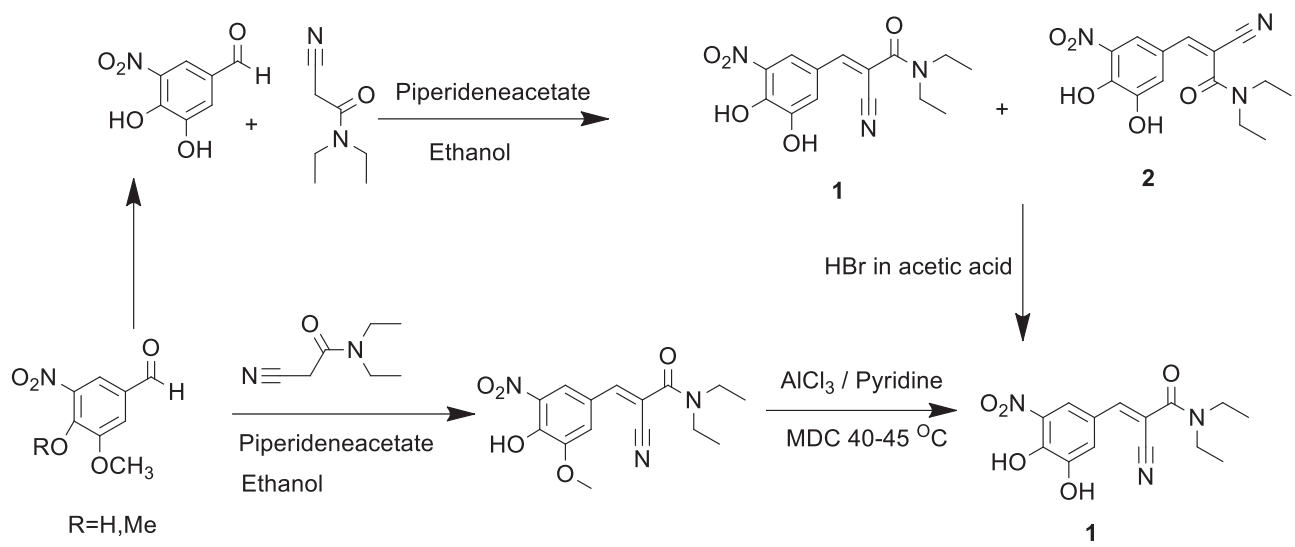

Scheme 1. Currently available method for the synthesis of $\mathbf{1}$.

and para (EWG) positions may be susceptible to nucleophilic attack by bases under mild conditions. There are some reports in the literature which encouraged us in this pursuit. Cahn et al., ${ }^{20}$ found a method for the dealkylation of phenolic ethers ortho to a nitro group by pyridine or piperidine. It is also reported by Conreaux et al. ${ }^{21}$ that 3-alkynyl-4-methoxy-2-pyridinones heated in a reaction mixture containing triethylamine for a prolonged time underwent dealkylation by $\mathrm{SN}_{2}$ mechanism.

\subsection{Successful demethylation- synthesis of entacapone}

We carried out initial model experiments with the substrate ethyl 2-cyano-3-(3, 4-dimethoxy-5-nitrophenyl) prop-2-enoate 4 which was obtained readily by condensation of 5-nitroveratraldehyde with ethyl cyanoacetate (scheme 2). Compound 4 was treated with triethylamine in ethanol at $70-75^{\circ} \mathrm{C}$ for $12 \mathrm{~h}$ and the solvent evaporated to a sticky solid. This was dissolved in water, acidified with hydrochloric acid and extracted into ethyl acetate. Evaporation of ethyl acetate layer gave crude demethylated product 6 which was purified by silica gel column chromatography to afford pure $\mathbf{6}$ in a gratifying yield of 58\%. This unknown compound had correct NMR and mass spectral properties and was identical to the product obtained by condensing 5-nitrovanillin 8 with ethyl cyanoacetate. A preliminary communication has reported these results. ${ }^{23}$ In another experiment acidification was done by aqueous hydroiodic acid and the acidic layer from the experiment was evaporated, washed with diethyl ether to give methyltriethylammonium iodide 7 , MR $327-328^{\circ} \mathrm{C}$, which was characterized by ${ }^{1} \mathrm{H}-\mathrm{NMR}$ spectrum in $\mathrm{D}_{2} \mathrm{O}$. The quaternary salt was identical with the product (MR and mix MR $327-328^{\circ} \mathrm{C}$ ) obtained by reaction of triethylamine with methyl iodide in ether ${ }^{22}$ at $20-25^{\circ} \mathrm{C}$. This established that reaction had occurred, as expected by nucleophilic attack of the methyl group on the C-4 methoxyl by triethylamine to give the demethylated product as an ammonium salt $\mathbf{5}$ with the phenoxide anion

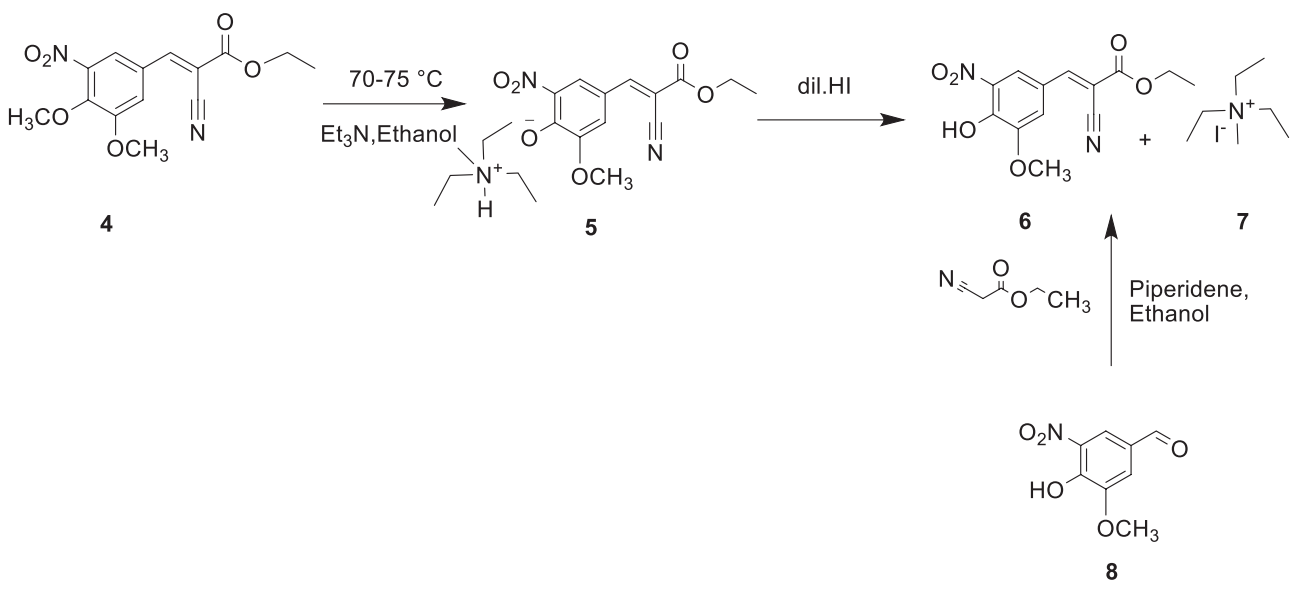

Scheme 2. Model demethylation. 
stabilized by extensive conjugation with the ortho placed $\mathrm{NO}_{2}$ group and acrylic derivative at the para position (scheme 3). It is obvious that an analogue of 4 with no methoxyl in the ortho position but only in the meta position which will be also meta located with respect to the acrylic side chain will not undergo demethylation since the methoxyl oxygen atom is not conjugating with the two electron withdrawing groups.

The optimum temperature for demethylation with triethylamine in ethanol was $70-75^{\circ} \mathrm{C}$; at a lower temperature $40-45^{\circ} \mathrm{C}$ there was no observable demethylation in ethanol during $12 \mathrm{~h}$. Demethylation was also observed with diethyl amine and piperidene in ethanol. Surprisingly, nucleophilic addition of these secondary amines to the electron-deficient double bond was not observed to any detectable level.

We then extended the demethylation to compound 2-cyano-3-(3,4-dimethoxy-5-nitrophenyl)-N,Ndiethylprop-2-enamide 9 from 5-nitrovertraldehyde and $\mathrm{N}, \mathrm{N}$-diethyl cyanoacetamide. ${ }^{11}$ Reaction of 9 with triethylamine in ethanol at $70-75^{\circ} \mathrm{C}$ for $12 \mathrm{~h}$ and the product worked up as earlier, followed by crystallization from ethyl acetate gave the expected known demethylated compound $\mathbf{1 0}$ in 56\% yield (scheme 4). This was identical to the product made by condensing 5-nitrovanillin with $N, N$-diethyl cyanoacetamide. ${ }^{11}$

Repetition of demethylation of $\mathbf{9}$ with diethylamine in ethanol at $50-55^{\circ} \mathrm{C}$ for $12 \mathrm{~h}$ gave $\mathbf{1 0}$ in $40 \%$ yield after chromatography.
Encouraged by these results we extended the reaction to ethyl 2-cyano-3-(3-hydroxy-4-methoxy5-nitrophenyl) prop-2-enoate 11 and 2-cyano-3-(3-hydroxy-4-methoxy-5-nitrophenyl) prop-2-eneamide 13. The last two were prepared from 5-nitroisovanillin by condensing with ethyl cyanoacetate and $\mathrm{N}, \mathrm{N}$-diethyl cyanoacetamide respectively. Upon heating $\mathbf{1 1}$ and $\mathbf{1 3}$ in ethanol with triethylamine at $70-75^{\circ} \mathrm{C}$ for $12 \mathrm{~h}$ and the usual workup, the expected catechol products, $\mathbf{1 2}^{24}$ and entacapone 1 were obtained in yields of $48 \%$ and $45 \%$, respectively (scheme 4) after silica gel chromatography.

In the case of 13 , the crude product was obtained showing very little $\mathrm{O}-\mathrm{CH}_{3}$ signal in the ${ }^{1} \mathrm{H}-\mathrm{NMR}$ spectrum at $\delta 4.0 \mathrm{ppm}$; also, significantly the main product was 1 with only traces of the Z- isomer $\mathbf{2}$ (LC). Considering that the starting material $\mathbf{1 3}$ was wholely the $\mathrm{E}$ isomer (vide infra), the demethylative process was not disruptive of the geometry, 1 (scheme 4). The product $\mathrm{mp} 162-163^{\circ} \mathrm{C}$ was identical with an authentic sample and was characterized extensively by NMR studies (vide infra).

Thus our objective of synthesizing 1 from a Omethylated precursor was realized in moderate yields in un-optimized experiments under mild conditions (scheme 4). ${ }^{23}$

\subsection{Scope of demethylation}

A limited number of experiments were then carried out to define the structural features needed for demethylation under our conditions. 5-Nitroveratraldehyde $\mathbf{1 4}$ itself

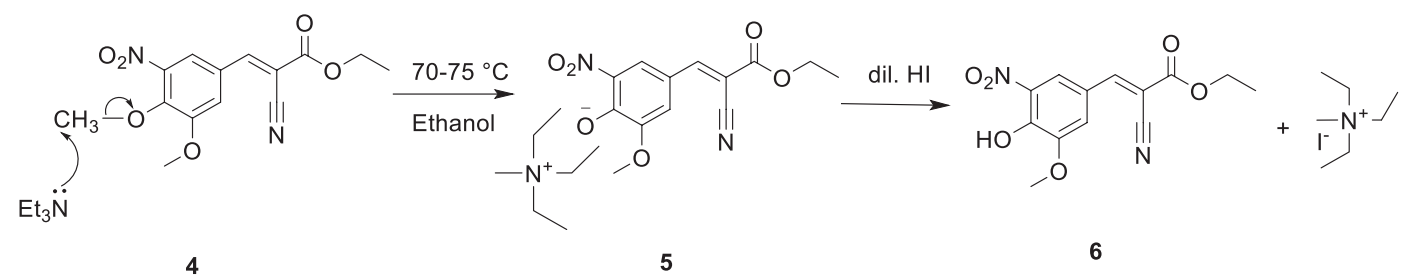

Scheme 3. Nucleophilic attack of the methyl group on the C-4 methoxyl by triethylamine.

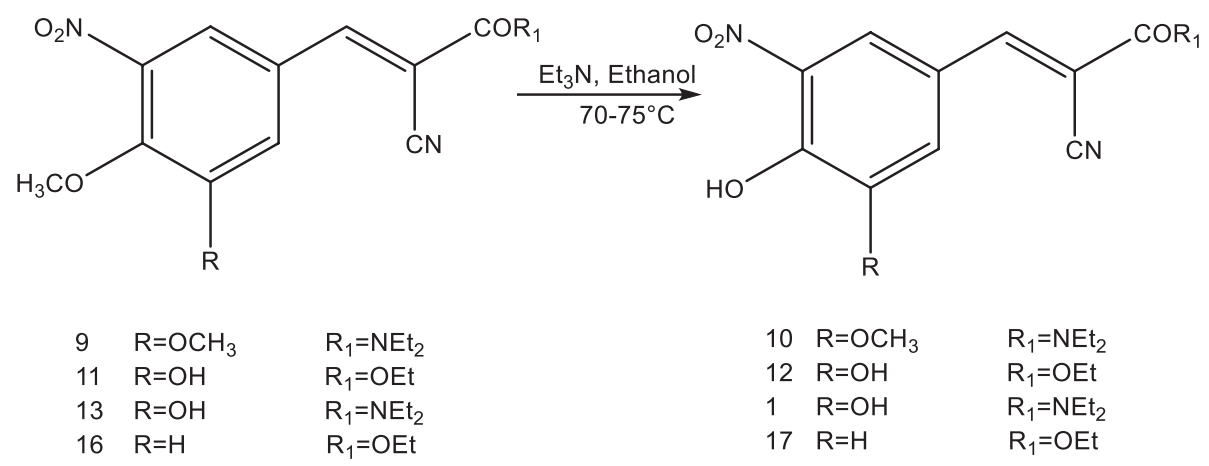

Scheme 4. Synthesis of entacapone 1 and some analogues. 


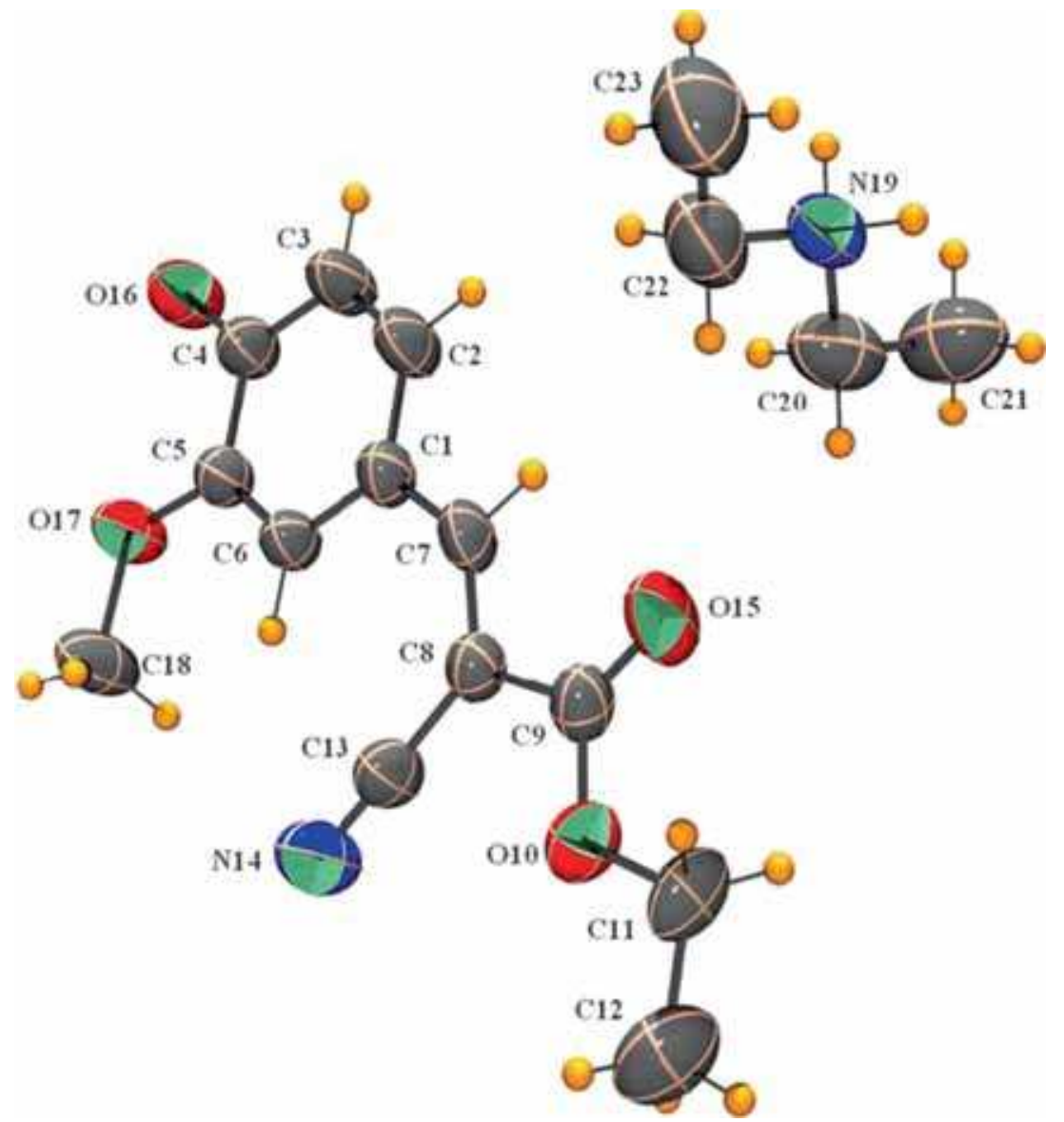

Figure 1. ORTEP diagram of compound 23.

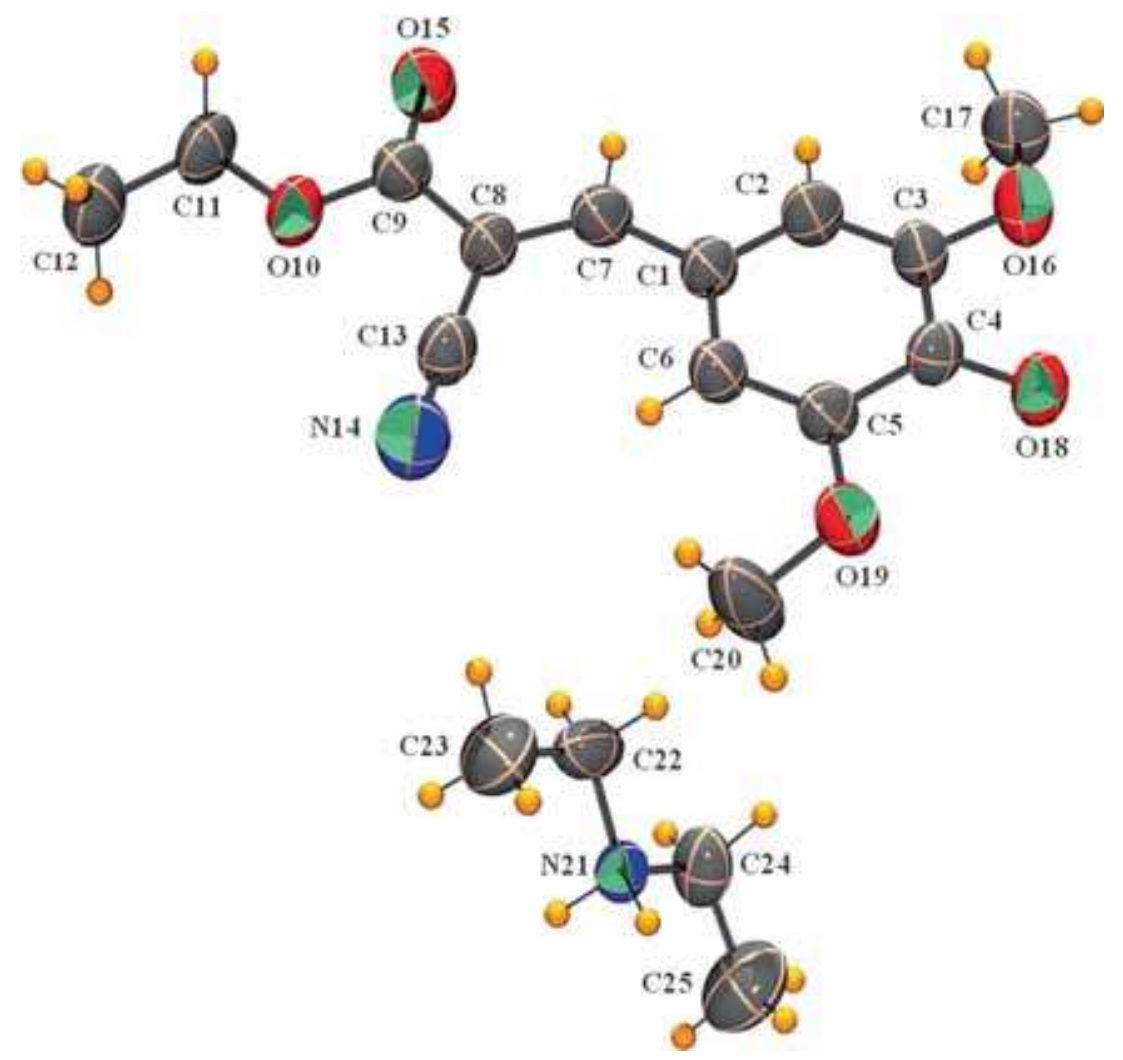

Figure 2. ORTEP diagram of compound 25. 
was also demethylated to 5-nitrovanillin 8. 4-Methoxy3-nitro derivative $\mathbf{1 6}$ underwent demethylation to $\mathbf{1 7}$ in hot ethanolic triethylamine (scheme 4). ${ }^{23}$ The nitrovanillin derived isomer $\mathbf{6}$ of $\mathbf{1 1}$, wherein methoxyl group was meta to the nitro was not demethylated by diethylamine in hot ethanol but gave the salt of $\mathbf{1 5}$ as also the corresponding $N, N$ diethylcyanoacetamide. ${ }^{11}$

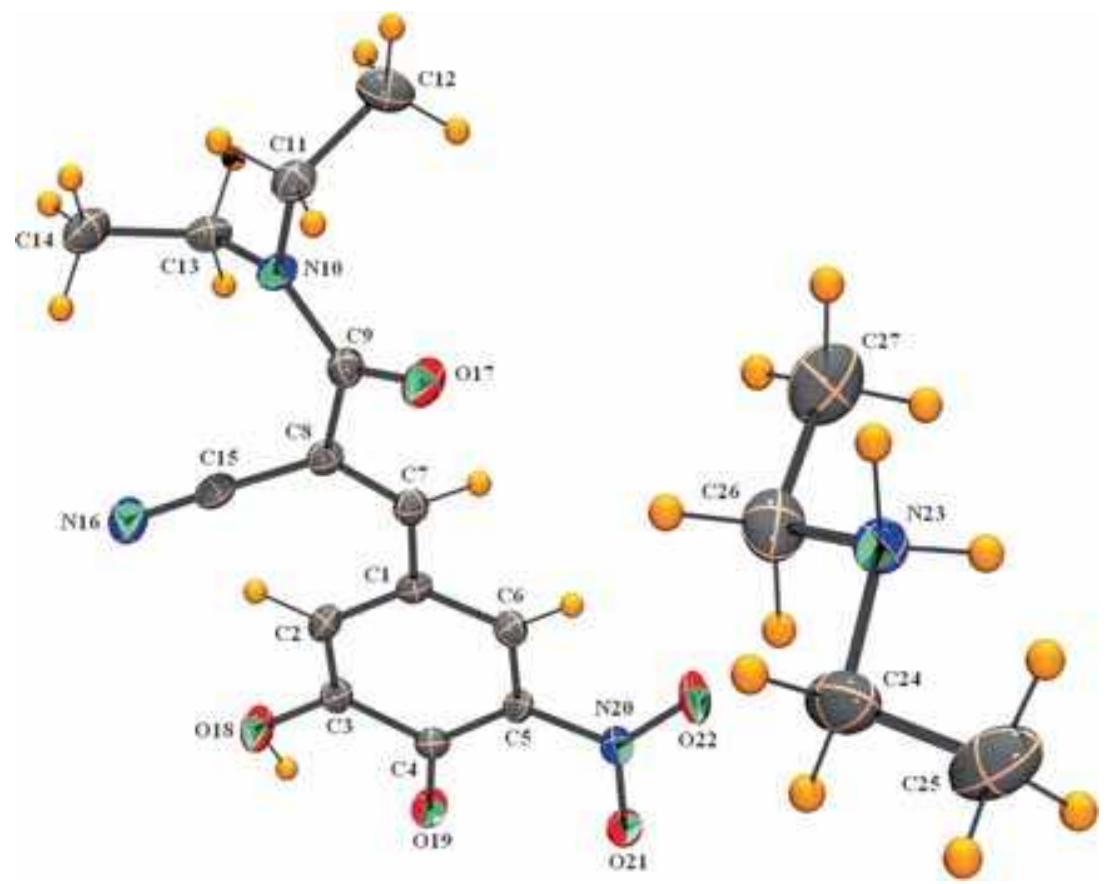

Figure 3. Single-crystal X-ray structure ORTEP diagram of diethyl amine salt $\mathbf{3 0}$ of $\mathbf{1}$.

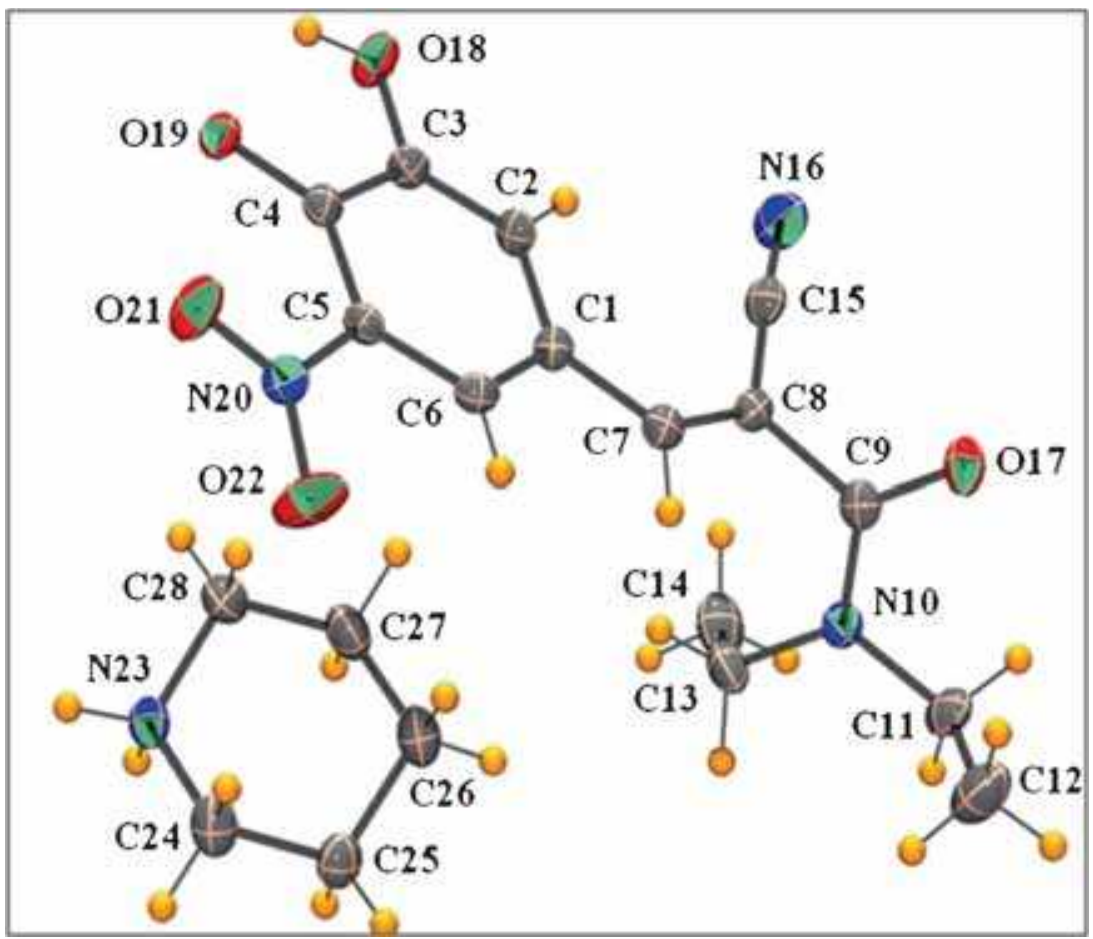

Figure 4. Single-crystal X-ray structure ORTEP diagram of piperidene salt $\mathbf{3 2}$ of $\mathbf{1}$. 
A regioisomer 18 was not demethylated but it underwent a unique reaction to give dihydro and butadiene products which were observed by us for a large number of analogues without a nitro group. The results have been published in our preliminary communication. ${ }^{23}$<smiles>CCOC(=O)/C(C)=C/c1cc([N+](=O)[O-])ccc1OC</smiles>

18

Another regioisomer 19 gave a complex mixture of products having a ${ }^{1} \mathrm{H}-\mathrm{NMR}$ spectrum wherein aromatic signals were shifted up field indicating reduction of the $\mathrm{NO}_{2}$ group. This was also observed for the desmethoxy derivative of 19 obtained from 2-nitrobenzaldehyde. A similar complex reaction was observed with nitrovertraldehyde derivative $\mathbf{2 0} .^{25}$<smiles>CCOC(=O)/C(C#N)=C/c1cccc(OC)c1[N+](=O)[O-]</smiles>

19<smiles>CCOC(=O)/C(=C/c1cc(OC)c(OC)cc1[N+](=O)[O-])C(=O)O</smiles>

20
Compounds $21^{26}$ and $\mathbf{2 2}^{11}$ without a $\mathrm{NO}_{2}$ group derived from vanillin gave only the salts of the amines used, under demethylation conditions. It has been shown in recent years that bases and acids can together form ionic salts or complexes. ${ }^{27}$<smiles>[R]C(=O)/C(C#N)=C/c1ccc(O)c(OC)c1</smiles>$$
21 \mathrm{R}=\mathrm{OC}_{2} \mathrm{H}_{5}
$$$$
22 \mathrm{R}=\mathrm{NEt}_{2}
$$

In the case of the diethylamine salt $\mathbf{2 3}$ from $\mathbf{2 1}$, single crystal X-ray studies showed that it was a formal salt and not a complex, with the basic nitrogen carrying two protons, as shown in figure $1 .^{27}$

This is also evident from a study of the ${ }^{1} \mathrm{H}-\mathrm{NMR}$ spectrum of $\mathbf{2 2}$ and its diethylammonium salt; signals of $\mathrm{H} 5$ at $\delta 6.94$ and vinyl $\mathrm{H}$ at $\delta 8.22$ were shifted to upfield to $\delta 6.34$ and $\delta 7.79$, respectively.<smiles>CCN[PH2+]Oc1ccc(/C=C(\C#N)C(=O)OCC)cc1OC</smiles>

Similar salt formation occurred with $\mathbf{2 4}$ derived from syringaldehyde upon attempted demethylation with diethylamine and piperidine. Single crystal X-ray of the diethylamine product $\mathbf{2 5}$ again showed that it was a formal salt and not a complex in spite of having additional electron donating methoxyls at both ortho positions. The ORTEP is shown in figure 2.<smiles>CCOC(=O)/C(C#N)=C/c1cc(OC)c(O)c(OC)c1</smiles><smiles>[BH2-]c1c(OC)cc(/C=C(\C#N)C(=O)OCC)cc1OC</smiles>

Lastly demethylation was attempted on the isovanillin derivatives $\mathbf{2 7}{ }^{28}$ and $\mathbf{2 8}$ with diethylamine and triethylamine.<smiles>[R]C(=O)/C(C#N)=C/c1ccc(OC)c(O)c1</smiles>

$27 \mathrm{R}=\mathrm{OEt}$

$28 \mathrm{R}=\mathrm{NEt}_{2}$

In both cases neither demethylation nor salt formation was observed. Obviously, the $\mathrm{OH}$ group is not acidic enough in the absence of para located cyanoacrylic groups.

From results obtained thus far, it can be concluded that O-demethylation with amines in hot solvents occurs in aromatic systems represented by 29 .<smiles>[R]O[X]</smiles>

29

It may also occur with the corresponding aldehydes although we have studied only one example $(3,4-$ dimethoxy-5-nitrobenzaldehyde).

Entacapone 1 which has wide spread clinical use has poor water solubility and water soluble derivatives may have some clinical usefulness. Our serendipitous observation of formation of salts in this study cited above encouraged us to make salts of $\mathbf{1}$ deliberately. Accordingly, we were able to obtain crystalline colored salts with diethylamine 30, triethylamine 31, piperidine 32, diisopropylethylamine $\mathbf{3 3}$ and morpholine 34. Among these, single X-ray structures of the diethylamine and piperidene salts are available. Their ORTEPS are shown in figures 3 and 4.

While there is one reference for the crystal structure of 1 showing E configuration as shown in figure 5, the 


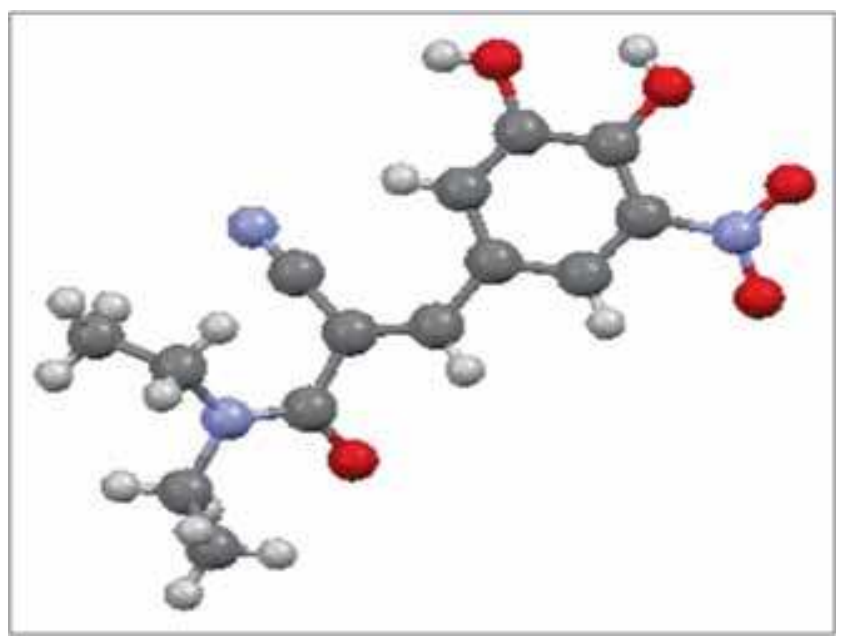

Figure 5. Single crystal X-ray structure ORTEP diagram of 1 .

same paper has such a study for the Z-isomer $\mathbf{2}$ only as the di-benzoate. ${ }^{29}$ Since $\mathbf{2}$ is a major metabolite in humans, it was considered worthwhile to do its crystal structure. We have been able to prepare good crystals of 2 and solve the crystal structure (table 1). The ORTEP is given in figure 6 .

Z-isomer 2 crystallizes in $P 2_{1} / \mathrm{c}$ space group. The crystal structure is stabilized by both intra and

Table 1. Crystal data and structure refinement for $\mathbf{2}$.

2

\begin{tabular}{lc} 
Molecular formula & $\mathrm{C}_{14} \mathrm{H}_{15} \mathrm{~N}_{3} \mathrm{O}_{5}$ \\
CCDC Number & 1027892 \\
Formula weight & 305.29 \\
Crystal system & Monoclinic \\
Space group & $P 22_{1} / \mathrm{c}$ \\
$\mathrm{a}(\AA)$ & $8.754(2)$ \\
$\mathrm{b}(\AA)$ & $8.061(2)$ \\
$\mathrm{c}(\AA)$ & $20.695(5)$ \\
$\alpha\left({ }^{\circ}\right)$ & 90 \\
$\beta\left({ }^{\circ}\right)$ & $93.491(8)$ \\
$\gamma\left({ }^{\circ}\right)$ & 90 \\
$\mathrm{~V}\left(\AA^{3}\right)$ & $1457.6(6)$ \\
$\mathrm{Z}$ & 4 \\
$\mu .\left(\mathrm{mm}^{-1}\right)$ & 0.11 \\
$\mathrm{~T}(\mathrm{~K})$ & $295(2)$ \\
$\lambda(\AA)$ & 0.71073 \\
$\mathrm{Reflns}^{\circ}$ Collected & 17038 \\
Unique reflns. $_{\text {Completeness }}(\%)$ & 2864 \\
$\mathrm{R}_{\text {int }}$ & 100 \\
$\mathrm{R}_{1}\left(\mathrm{~F}^{2}\right)$ & 0.065 \\
$w \mathrm{R}_{2}\left(\mathrm{~F}^{2}\right)$ & 0.04 \\
Goodness-of-fit $_{\text {Resolution }(2 \theta)}$ & 0.096 \\
R $\left.^{\circ}\right)$ & 0.98 \\
\hline
\end{tabular}

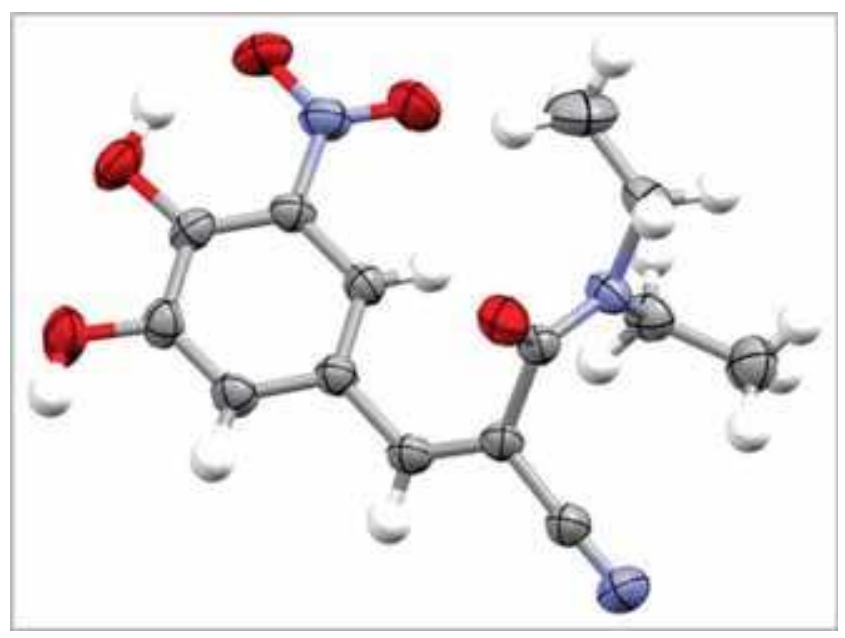

Figure 6. Single crystal X-ray structure ORTEP diagram of 2 .

intermolecular hydrogen bonding, as well as $\pi \ldots \pi$ interactions. The packing diagram is shown in figure 7 .

Gas phase optimized energies were calculated for both the isomers (1 and 2) using Gaussian09. The calculation shows that after optimization $\mathbf{2}$, shown in figure 8 , is stabler by $-3.1 \mathrm{kcal}$ than the optimized $\mathbf{1}$, shown in figure 9.

The energy minimization was also carried out for both isomers using ChemBio3D Ultra 12.0 software running on MS-Windows 7 using MM2 Force Field method. Temperature was set $300 \mathrm{~K}$. In total, 727 iterations were set for the process to complete the energy minimization step. It is interesting to note that the energy minimized structures of $\mathbf{1}$ and $\mathbf{2}$, as shown figures 10 and 11, respectively show very strong similarities with the respective crystal structures. We have calculated the energies to be $6.88 \mathrm{kcal} / \mathrm{mole}$ and $-1.45 \mathrm{kcal} / \mathrm{mol}$, respectively for $\mathbf{1}$ and $\mathbf{2}$ forms with 2 again being stabler than 1 by $-8.03 \mathrm{kcal}$. The implications of these intriguing results need further study.

\subsection{NMR studies on 1 and 2 and other arylidenecyanoacetic acid derivatives}

We also extended our studies elaborating the methods for determination of $\mathrm{E}$ and $\mathrm{Z}$ configurations in such molecules using NMR techniques. A few interesting observations on the rotational isomerism around the amide bond were also noted.

In the $500 \mathrm{MHz}{ }^{1} \mathrm{HNMR}$ spectrum of 1 in $\mathrm{CDCl}_{3}$ the four $\mathrm{CH}_{2}$ proton of the amide were seen as a broadened singlet at $3.52 \mathrm{ppm}$ (instead of the usual quartet). This broadening has been noticed already in the $400 \mathrm{MHz}$ proton spectra of $\mathbf{1}$ as its monopivaloate 


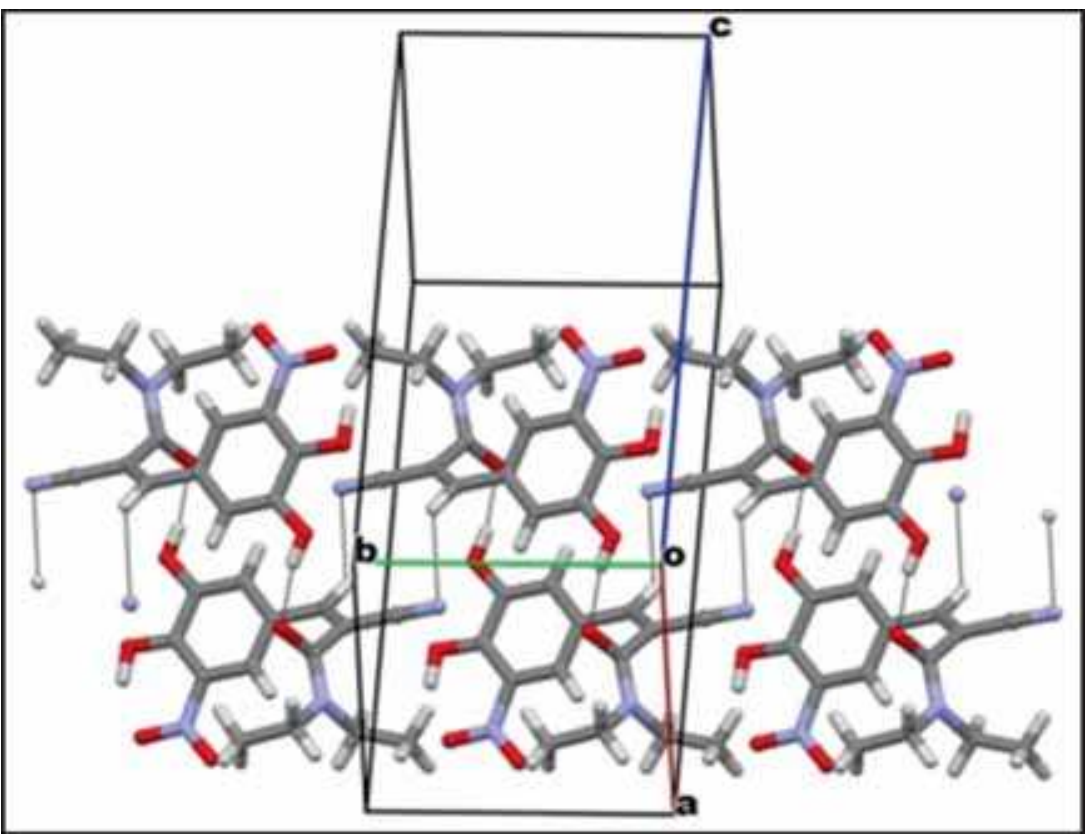

Figure 7. Intra and intermolecular hydrogen bonding of 2.
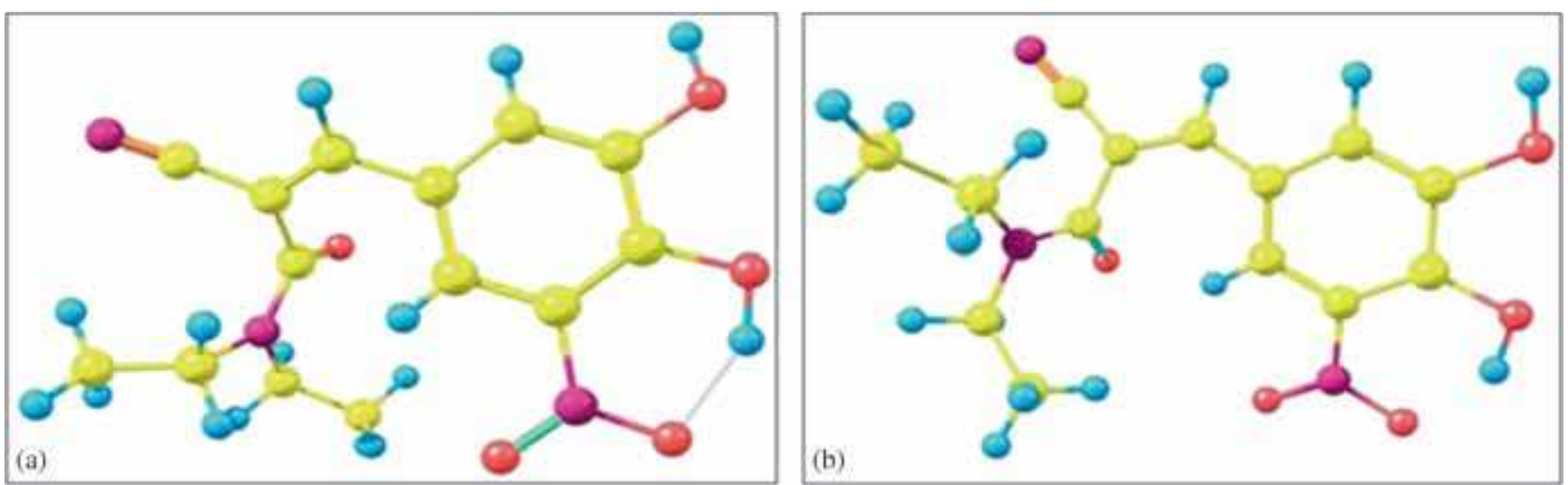

Figure 8. (a) Initial geometry (b) Optimized geometry for 2.
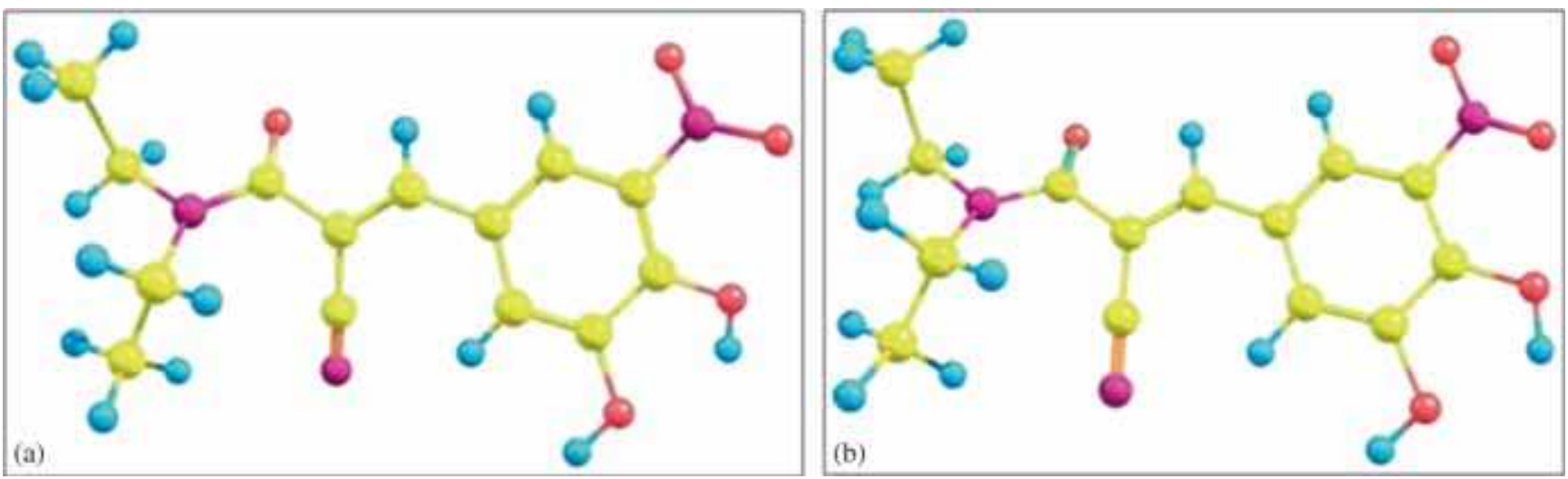

Figure 9. (a) Initial geometry (b) Optimized geometry for $\mathbf{1}$. 


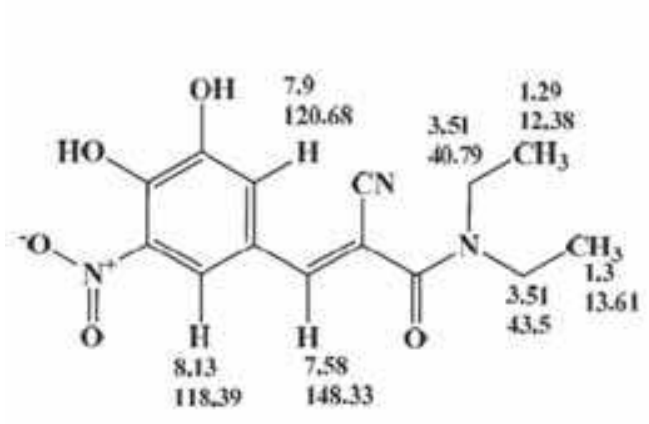

2D $1 \mathrm{H}-1 \mathrm{H}$ NOESY spectra

(expanded region)

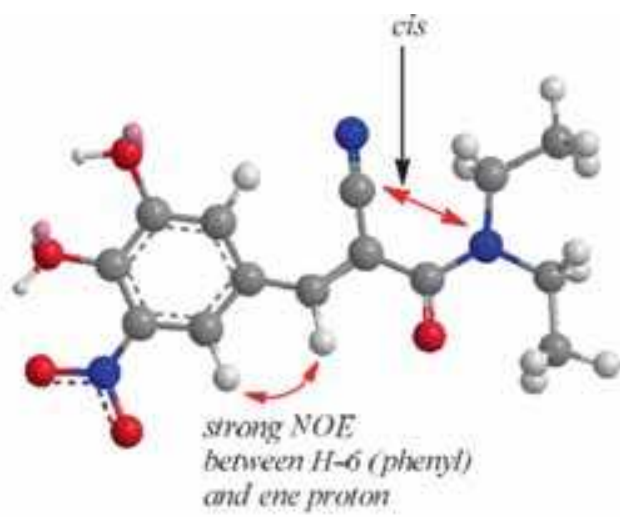

and ene proton

Figure 10. 2D 1H-1H NOESY spectrum of $\mathbf{1}$.
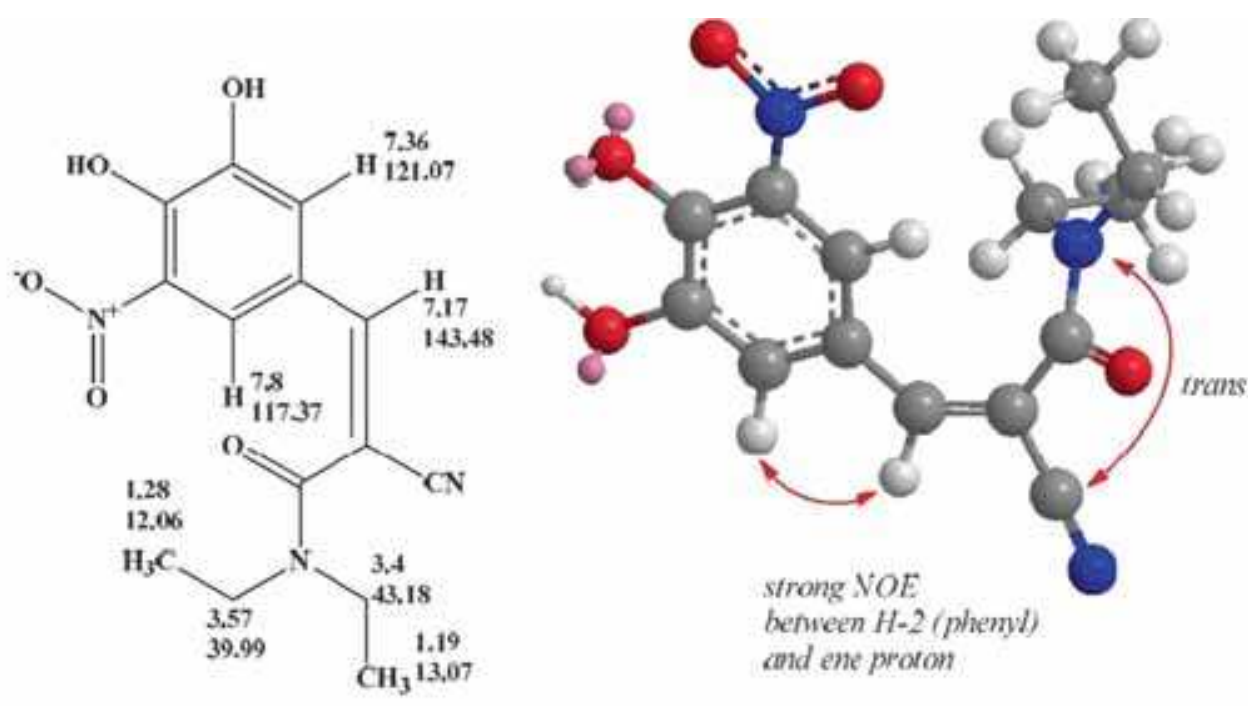

2D $1 \mathrm{H}-1 \mathrm{H}$ NOESY spectra

(expanded region)

Figure 11. 2D 1H-1H NOESY spectrum of 2.

and dibenzoate. ${ }^{29}$ The corresponding $\mathrm{C}$ atom showed two peaks, $\delta 43.42$ and 40.72 (the latter overlaps with the carbon signals of DMSO-d6). ${ }^{13} \mathrm{C}$ HSQC showed that the broad signal in the proton NMR at $3.52 \mathrm{ppm}$ was correlated with the above two ${ }^{13} \mathrm{C}$ signals. Likewise, the two $\mathrm{CH}_{3}$ protons were seen as two broad singlets of 1.32 and $1.28 \mathrm{ppm}$, respectively, correlating in ${ }^{13} \mathrm{C}$-HSQC with carbon signals at 13.50 and 12.60 ppm, respectively. The above data indicate that rotation around the amide carbonyl was slower in the ${ }^{13} \mathrm{C}$ NMR time scale than in the proton NMR time scale. The ${ }^{1} \mathrm{H}$ NMR spectra of other enamides 9, 10, 13 and 28 reported in this paper as well as the salts of entacapone also exhibited broad peaks for the methyl and methylene protons.
The ${ }^{1} \mathrm{H}$ and ${ }^{13} \mathrm{C}$ NMR spectra of the $\mathbf{2}$ however gave two sets of clean quartets for the methylene protons ( $\delta 3.43$ and 3.26) and two well defined triplets for the methyl protons ( $\delta 1.10$ and 1.01) respectively. In the ${ }^{13} \mathrm{C}$ NMR, the methylene carbon gave two peaks at $\delta 43.25$ and 39.98 (overlapping with DMSO-d6 carbon signals) and methyl carbons at $\delta 13.88$ and 12.22. ${ }^{13} \mathrm{C}$-HSQC showed correlation between ${ }^{1} \mathrm{H}$ singlets at $\delta 3.43,3.26,1.10$ and 1.01 , respectively with carbon signals at $\delta 39.98,43.25,12.22$ and 13.88. Results reported for 2 benzoate are similar. ${ }^{29}$ From these observations it appears that the barrier to free rotation of the amide bond is less in $\mathbf{1}$ than in $\mathbf{2}$.

In the first attempt at assigning $\mathrm{E}$ and $\mathrm{Z}$ configurations for $\mathbf{1}$ and $\mathbf{2}$, respectively, we utilized their energy 
minimized structures $\mathbf{1 0}$ and 11. As expected, in the $2 \mathrm{D}{ }^{1} \mathrm{H}-{ }^{1} \mathrm{H}$ NOESY spectrum of $\mathbf{1}$ (Figure 10) there was a strong NOE behave the ene and H-6 protons. In the similar spectrum for the 2 (Figure 11), there was a strong NOE between the ene and $\mathrm{H}-2$ protons.

We could achieve even stronger confirmation by studying the coupling between the $\mathrm{C}=\mathrm{O}$ and $\mathrm{CN}$ carbons with the ene proton in the $\mathbf{1}$ and $\mathbf{2}$. It was shown earlier by one of us ${ }^{30}$ and others ${ }^{38}$ that the ${ }^{3} J$ C-H coupling in the ethylenic systems A and B are geometry dependent with the $J$ values for trans being higher than the cis.

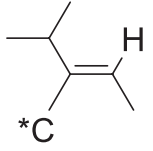

A

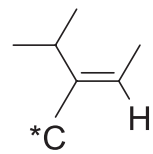

B
For this exercise, we studied the ${ }^{1} \mathrm{H}$ coupled ${ }^{13} \mathrm{C}$ spectra of model compounds $\mathbf{3 5}^{31}$ and $\mathbf{3 6}^{32}$ and obtained the $3 J \mathrm{H}-\mathrm{C}$ values (table 2.). In the fully proton coupled carbon spectra of $\mathbf{1}$ and $\mathbf{2}$, we got values clearly confirming our previous deductions of $\mathrm{H}$ atom and $\mathrm{CO}$ group being cis in $\mathbf{1}$ and trans in $\mathbf{2}$ (table 3), thus confirming $\mathrm{E}$ and $\mathrm{Z}$ geometries respectively for $\mathbf{1}$ and $\mathbf{2}$. Data presented in (table 3) for compounds $\mathbf{1 1}$ and $\mathbf{1 3}$ also establish their geometry as being E. Noting that the chemical shifts of the ene protons in the arylidenecyanoacetates discussed in this paper have chemical shifts of around $\delta 8 \mathrm{ppm}$ and the cyanodiethylamides with the exception of $\mathbf{2}$ around $7 \mathrm{ppm}$, they can all be assigned the E geometry as shown in their respective structures.

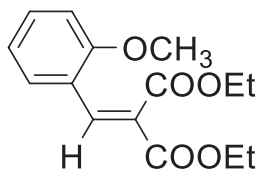

35

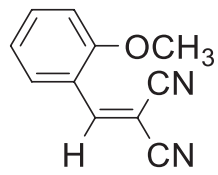

36
We extended the technique to assign the geometry of ethyl benzylidenebenzoylacetate $\mathbf{3 7}$ (synthesized as per literature,,$^{33} \mathrm{MR} 88-89^{\circ} \mathrm{C}$ ), as literature reports have been conflicting in the configuration assignment. The reports have not given definitive proof for the assignments of configurations expect for the single crystal

Table 2. ${ }^{1} \mathrm{H}$ coupled ${ }^{13} \mathrm{C}$ spectra of compounds $\mathbf{3 5}$ and $\mathbf{3 6}$.

\begin{tabular}{lll}
\hline & \multicolumn{3}{c}{${ }^{3} J \mathrm{C}-\mathrm{H}$} \\
\cline { 2 - 3 } & trans & cis \\
\hline $\mathbf{3 5}$ & 12.2 & 7.4 \\
$\mathbf{3 6}$ & 14.4 & 8.5 \\
\hline
\end{tabular}

Table 3. Proton coupled carbon for 1, 2,11 and 13 .

\begin{tabular}{|c|c|c|c|c|}
\hline & ${ }^{3} J$ & $\begin{array}{l}\mathrm{C}-\mathrm{H} \\
\| \\
\mathrm{O}\end{array}$ & ${ }^{3} J$ & $\begin{array}{l}\mathrm{C} \\
\mathrm{II}\end{array}$ \\
\hline 1 & & 5.78 & & 14.0 \\
\hline 2 & & 10.26 & & 9.38 \\
\hline 11 & & 6.94 & & 14.03 \\
\hline 13 & & 7.4 & & 14.05 \\
\hline
\end{tabular}

X-ray studies published in 2006, which revealed a Econfiguration $37 .{ }^{33}$ The compound has been shown as the E-isomer by Woo-Jin Yoo et al. ${ }^{34}$ but with no evidence. Likewise, Zhiping Li et al. ${ }^{35}$ and Chris D Smith et al., ${ }^{36}$ have assigned the E-structure by ${ }^{1} \mathrm{H}-\mathrm{NMR}$. In the paper of Jose Barluenga et al., ${ }^{37}$ the compound has been obtained as a 70:30 mixture of inseparable $\mathrm{Z} / \mathrm{E}$ isomers. The major isomer is said to be $\mathrm{Z}$, but in the light of our studies and X-ray, it is really E. Surprisingly, all these papers, including the X-ray crystallographic study, ${ }^{33}$ have ignored the seminal paper of Kingsbury et al. ${ }^{38}$ who have derived the current configuration by using ${ }^{13} \mathrm{C}-\mathrm{H}$ splitting for this molecule. While confirming this assignment by our own study of ${ }^{13} \mathrm{C}$-H couplings [ $\delta \mathrm{Ph} . \mathrm{CO}, 195.5 \mathrm{ppm}, 3 \mathrm{~J} \mathrm{CH}$ (ene proton), $10.2 \mathrm{~Hz}$; $\delta \mathbf{C O} . \mathrm{OEt}, 164.7 \mathrm{ppm}, 3 \mathrm{~J} \mathrm{CH}$ (ene proton), $8.3 \mathrm{~Hz}$, we are providing independent proof from NOESY studies. Thus, the ene proton shows significant NOES with $\mathrm{CH}_{2}$ and $\mathrm{CH}_{3}$ protons of the ester which is possible only in the E-configuration 37.

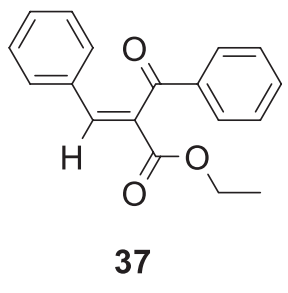

\subsection{Biological activities of 1 and analogues}

In a recent article, based upon docking studies with the InhA,${ }^{39}$ entacapone 1 was expected to have anti-TB activity which was confirmed by in vitro studies. The MIC was reported to be between 62.5 and $125 \mu \mathrm{g} / \mathrm{ml}$. Importantly, it has been noted that it can be useful for treating MDR and XDR TB infections. In the course of our research, we had access to $\mathbf{1}$ and several analogues (some not reported in this paper) which were examined for in vitro anti-TB activity against Mtb H37Ra/Rv were more active with MIC of $12.5 \mu \mathrm{M}$. These are being studied further for activity against resistant TB and cytotoxicity. Likewise, there have been literature 
reports of molecules with an $\alpha, \beta$-unsaturated carbonyl system having in vitro anti-dengue activity. ${ }^{40}$ Gratifyingly, some of our molecules did show this activity. ${ }^{41}$ We plan to continue our studies to realize the potentials uncovered so far for molecules like $\mathbf{1}$ in the treatment of resistant TB and dengue for which no therapy is available as of now and report the results in the future.

\section{Conclusions}

We have demonstrated the vulnerability to amines under mild conditions, of an aromatic methoxyl adjacent to a nitro group and having strong electron withdrawing groups in the para position and applied it to produce entacapone $\mathbf{1}$, a clinically used adjuvant for the treatment of Parkinson's disease. X-ray crystal structure of the major human metabolite $\mathbf{2}$ has been established. Extensive NMR studies have also been carried out to derive the geometry of 1,2 and similar molecules. Early indications of anti-TB and antidengue activities for some molecules reported in this paper will be pursued.

\section{Supplementary Information}

${ }^{1} \mathrm{H},{ }^{13} \mathrm{C}$ NMR, HSQC and 2D 1H-1H NOESY spectra for all new compounds are available. available at www.ias.ac.in/chemsci. Crystallographic data $\mathbf{2}$ (CCDC1027892), 23 (CCDC1027891), 25 (CCDC10 27893), 30 (CCDC1027894) and 32 (1027895) have been deposited at the Cambridge Crystallographic Database Centre and are available on request (http: www.ccdc.cam.ac.uk).

\section{Acknowledgements}

We thank Alkem laboratories of India for providing research facilities and OSDD CSIR for in vitro anti TB results.

\section{References}

1. Axelrod J and Albers W 1959 Carmine and Clemente D J. Neurochem. 568

2. Richard C, Dodel M D, Karla M, Eggert M D, Marika S, Singer M D, Eichhorn E., M D Oliver Pogarell M D, Wolfgang H and Oertel M D 1998 Mov. Disord. 13249

3. Andrew D, Siderowf M D, Robert G, Holloway M D, MPH and Stern M B 2000 Mov. Disord. 15439

4. Axelrod J and Tomchick R 1958 J. Biol. Chem. 233702

5. Cedarbaum J M 1987 Clin. Pharmacokinet. 13141

6. Quinn N P 1984 Drugs 28236

7. Bartholini G and Pletscher A 1975 Pharmacol. Ther. [B] 1407

8. Mannisto P T and Kakkola S 1999 Phrmacol. Rev. 51 593
9. Wikberg T, Vuorela A, Ottoila P and Taskinen J 1993 Drug Metab. Dispos 2181

10. Pipuri, Honkanen and Haarala 1991 EP Patent $0,426,468$

11. Veera Reddy A and Rajendiran C 2005 WO Patent 2005063693 $\mathrm{A}_{1}$

12. Cziaky Z 2006 WO Patent $2006064296 \mathrm{~A}_{1}$

13. Bartra Sanmarti M, Solsona Rocabert J G, Palomo Nicolau F E and Molina Ponce A 2008 WO Patent 2008119793

14. Srikanth G, Ray Uttam Kumar, Srinivas Rao D V N, Badarinath Gupta P, Lavanya P and Islam Aminul 2012 Synth. Commun. 421359

15. Veerareddy A and Reddy G S 2014 Synth. Commun. 44 1274

16. Kulkarni P P, Kadam A J, Mane R B, Uday V D and Wadgaonkar P P 1999 J. Chem. Res. (S) 394

17. Buckle D R and Rockell C 1985 J. Chem. Soc., Perkin Trans. 12443

18. Arcadi A, Cacchi S, Del Rosario M, Fabrizi G and Marinelli F 1996 J. Org. Chem. 619280

19. Nishioka H, Nagasawa M and Yoshida K 2000 Synthesis 2243

20. Cahn R S 1931 J. Chem. Soc. 1121

21. Conreaux D, Belot S, Desbordes P, Monteiro N and Balme G 2008 J. Org. Chem. 738619

22. Brescia A, Arents J, Meislich H and Turk A 1973 In Fundamental of chemistry ( $3^{\text {rd }}$ ed.) (London: Academic press) p.413

23. Harisha A S, Nayak S P, Nagarajan K, Guru Row T N and Amar A. Hosamani 2015 Tetrahedron Lett. 561427

24. Zhang S J, Zheng X M and Hu W X 2009 Acta Crystallogr. Sect. E 652351

25. Kametani T, Nyu K and Yamanaka T 1971 Chem. Pharm. Bull. 191321

26. Dai G, Shi D, Zhou L and Huaxue L Y 1995 Chinese J. Appl. Chem. 3103

27. Sreenivas Reddy L, Sarah J, Bethune Jeff W. Kampf and Nair Rodriguez-Hornedo 2009 Cryst. Growth Des. 9378

28. Mitra A K, Banerjee S K and Sharmistha C 2003 J. Indian Chem. Soc. 80921

29. Leppanen J, Wegelius E, Nevalainen T, Jarvinen T, Gynther J and Huuskonen J 2001 J. Mol. Struct. 562129

30. Ulrich V, Wolfgang V P, Nagarajan K and Nair M D 1978 HeIv. Chim. Acta 61607

31. Francisco D, Joaquin T, Gerard Z, Miguel L, Rene M and Jose G 1995 Synth. Commun. 25753

32. (a) Saito T, Goto H, Honda K and Fujii T 1992 Tetrahedron Lett. 33 7553; (b) Angeletti E, Canepa C, Martinetti G and Venturello P 1988 Tetrahedron Lett. 29 2261; (c) Prajapti D, Lekhok K C, Snadhu J S and Ghosh A C 1996 J. Chem. Soc., Perkin Trans. 1 959; (d) Chalais S, Laszlo P and Mathy A 1985 Tetrahedron Lett. 264453

33. Hema R, Parthasarathi V, Ravikumar K, Sridhar B and Pandiarajan K 2006 Acta Crystallogr. Sect. E 62708

34. Yoo W J and Li C J 2006 J. Org. Chem. 716266

35. Li Z, Li H, Guo X, Cao L, yu Rango, Li H and Pan S 2008 Org. Lett. 10803

36. Smith C D, Rosocha G, Mui L and Batey R A $2010 \mathrm{~J}$. Org. Chem. 754716

37. Barluenga J, Riesgo L, Vicente R, Lopez Luis A and Tomas M 2007 J. Am. Chem. Soc. 1297772

38. Kingsbury C A, Draney D, Sopchik A, Rissler W and Durham D 1976 J. Org. Chem. 413863 
39. Kinnings S L, Liu N, Buchmeier N, Tonge P J, Xie L and Bourne P E 2009 Comput. Biol. 57

40. (a) Steuer C, Gege C, Fischl W, Karl H, Heinonen, Bartenschlager R and Klein C D 2011 Bioorg. Med. Chem. 19 4067; (b) Nitsche C, Steuer C and Klein C D 2011 Bioorg. Med. Chem. 19 7318; (c) Mueller N H,
Pattabiraman N, Ansarah-Sobrinho C, Viswanathan P, Pierson T C and Padmanabhan R 2008 Antimicrob. Agents Chemother. 52338541.

41. Padmanabhan R, Nagarajan K, Rao K S, Shridhara K, Shashiprabha and Harisha A S 2014 WO Patent 2014164667A 